\title{
Poultry Production System in Mauritania before the Activities of the "Program to Alleviate Rural Poverty through Support to Subsectors" (ProLPRAF)
}

\author{
Salimata Pousga ${ }^{1}$, Cheikh Ben Maali $^{2} \&$ Georges Anicet Ouedraogo ${ }^{3}$ \\ ${ }^{1}$ Associate Poultry Advisor Programm, FAO, Mauritania \\ ${ }^{2}$ Ministère de l'Agriculture, 180 Avenue Moctar Ould Dadah, Tevgah Zeina, Nouakchott, Mauritanie \\ ${ }^{3}$ Institut du Développement Rural, Université Nazi Boni, BP 1091, Bobo-Dioulasso, Burkina Faso \\ Correspondence: Salimata Pousga, Institut du Développement Rural, Université Nazi Boni, BP 1091, \\ Bobo-Dioulasso, Burkina Faso. Tel: 226-7109-2576. E-mail: pousgasalimata@yahoo.fr
}

Received: June 3, 2019 Accepted: June 28, 2019 Online Published: July 25, 2019

doi:10.5539/sar.v8n3p49 URL: https://doi.org/10.5539/sar.v8n3p49

\begin{abstract}
The objective of the present study was to display the state of poultry production in fourth (4) regions (Nouakchott, Hodh El Gharbi, Assaba and Guidimaka) covered by ProLPRAF program at the beginning of the program activities in 2011. Data were collected during surveys with different questionnaires addressed to different actors of the poultry sector.

Results from farmers showed that $65.0 \%$ were female with average age of $45.3 \pm 8.40$ years. Production constraints remained the same as those encountered in poultry farming in developing countries. There were no poultry markets in the regions, poultry sellers in Nouakchott were male $(100 \%)$ with average age of $34.8 \pm 5.2$ years. Traditional local chicken marketed in the regions came either from Nouakchott region (40\%) and others (40\%), or imported from neighboring countries $(20 \%)$. In modern poultry farming, day-old chick was imported from Morocco $(85 \%)$ or Senegal $(15 \%)$ as well as production inputs. The price of local chicken ranged from $1385 \pm 126$ to $2325 \pm 275 \mathrm{MU}$, while broiler chicken was between $1255 \pm 60$ and $1470 \pm 47 \mathrm{MU}$. Local chicken was for ritual, traditions and practices (75\%). Layer's Eggs were imported from Morocco (55\%) or Senegal (45\%), and average unit price of one egg was around 43.0 \pm 5.0 MU. Poultry meat cooked in the restaurants consisted exclusively of broilers meat (100\%).

Poultry farming was facing socio-political constraints that limited its development, but the ProLPRAF program has been able to tackle these constraints and the impact of the program is plausible today.
\end{abstract}

Keywords: ProLPRAF, inventory, Mauritania, poultry sector

\section{Introduction}

Mauritania is a Sahelo-Saharan country located in northwestern Africa, between the 15th and 27th degrees north latitude and the 5th and 17th degrees west longitude, with an area of $1,030,700 \mathrm{~km}^{2}$. Limited to the northwest by Western Sahara, to the north by Morocco, and Algeria, to the east and south-east by Mali and to the south by Senegal, Mauritania opens to the west on The Atlantic Ocean. The population was estimated in 2010 at about 3.5 and in 2017 to about 4.42 millions (World Bank, 2018). The poor rural population was estimated at 2 million people, $52 \%$ of whom were women. Livestock is the second largest resource in the country's economy after fishing, with an estimated contribution of $14.3 \%$ of GDP and nearly $80 \%$ of the value added of the rural sector (FAO, 2002). The herd was estimated at 1.3 million camelins, 1.4 million cattle, nearly 14 million small ruminants and 3.400,000 poultry. As a result, livestock provided a high degree of self-sufficiency in red meat with the opportunity to export live cattle to the countries of the sub-region. White meat production was done at $58 \%$ by traditional poultry farming, $25 \%$ by intensive poultry farming and $17 \%$ by imports (FAO, 2002). Traditional poultry farming remains interesting because of its role in household food security and, above all, because of its significant potential for improvement (FAO, 2002).

It was reported that Mauritanian imports of poultry products were equal to and / or surpassed even those of neighboring countries such as Senegal and Côte d'Ivoire, despite the fact that the population of Mauritania was 
much lower than that of these countries (nearly 4 times lower than in Senegal and nearly 6 times that of Côte d'Ivoire) (FAO, 2009). It seemed that in a near future, even on a favorable hypothesis and despite the existence of a certain growth potential, local production could hardly cover a growing demand. In this context, the development of poultry production should meet both the requirements of an increase in productivity to satisfy an increasing demand for white meat and the maintenance of activity in rural areas in order to combat the rural exodus and poverty.

The IFAD-funded Program to Combat Rural Poverty through Support to Subsectors (ProLPRAF) focused on developing seven sectors: poultry farming, vegetable garden, hides and skins, non-timber forest products, milk productions, dates production and red meats production in arid rural areas of Mauritania (IFAD, 2014). With regard to the poultry sector, the objective of the project was to develop a poultry sector focused on one hand, on improving the productivity of family poultry and on the other hand, the development of intensive poultry farming to ensure a foreign exchange economy by import substitution with local poultry products.

After five years of implementation of the poultry sector of this Program, several indicators now show that the intervention approach that was initiated had direct impacts in improving the income of rural producer groups composed mainly of poor women, who are engaged exclusively in traditional poultry farming (N'Diaye, 2016).

The present study carried out under this program consisted in making the inventory of the family poultry in fourth Wilayas (regions) of intervention of the program at the beginning of this one.

\section{Materials and Methods}

\subsection{Materials}

\subsubsection{Study Site}

The study sites concerned three regions that were part of the ProLPRAF intervention zone and the region of Nouakchott. The city of Nouakchott, capital of the Islamic Republic of Mauritania (RIM) is located in the southwest of the country on the Atlantic Coast. The wilaya (region) of Aassaba is located about $600 \mathrm{~km}$ east of the city of Nouakchott. A little further east is the region of Hodh El Gharbi (800km from Nouakchott) while to the south is the region of Guidimaka $(680 \mathrm{~km}$ from Nouakchott) near the Malian border.

\subsubsection{General Data}

The average temperature in RIM varies between 24 and 25 degrees Celsius with maxima and minima up to 50 and 17 degrees, respectively. Annual rainfall varies from $400 \mathrm{~mm}$ in the south to $100 \mathrm{~mm}$ in the north of the Sahelian part. In the north, rainfall becomes erratic and the annual average is insignificant (FAO, 2010).

\subsubsection{Soils and Plants}

The city of Nouakchott has a sandy soil with sand dunes observable on the outskirts. The observable plant species were among others the date palm (Phoenix dactylifera), the Prosopis juniflora, and the Azadiracta indica, (neem).

The regions of Assaba and Hodh El Gharbi in the Sahelian zone have a rainfall ranging from 150 to $350 \mathrm{~mm}$. Soils are rocky and dune belts are common. The plant species encountered were dominated by Phoenix dactilifera, Prosopis juniflora, Acacia albida, Calotropis proceras and Balanites aegyptiaca etc. The main activities of the rural world included: livestock (cattle, sheep, goats, camelins, and poultry), agriculture (Sorghum and cowpea in particular) and vegetable gardening in oasis including the cultivation of dates. The Guidimaka region in the Sudano-Sahelian zone is characterized by rainfall of more than $400 \mathrm{~mm}$ and has red iso-humic soils (FAO, 2000). The plant species encountered were: Borassus flabelifer L, Ziziphus mauritana, Adansonia digitata, Balanites aegyptiaca, to which was added an herbaceous carpet during the rainy season. The activities of the rural world were dominated by agriculture and livestock.

\subsection{Methodology}

The study was coordinated by the ProLPRAF Program. Thus, data collection was done at the same time as the missions organized by the project's poultry program team. A prospecting mission was first carried out to select the 3 regions of the study. The city of Nouakchott had also been involved, with the capital being considered as a large shopping center that could provide more information on the flow of trade in chickens and their products. The three regions concerned were Assaba, Hodh El Gharbi and Guidimaka, which were part of the ProLPRAF poultry intervention areas.

\subsubsection{Questionnaires}

Data were collected during surveys using two sets of questionnaires. One type of questionnaire was sent to 
poultry farmers while the other type was sent to other actors in the poultry sector (sellers of live chickens, egg sellers and sellers of cooked chickens and eggs).

The questionnaire to the farmers included questions on socio-economic characteristics, constraints on family poultry, and questions on general perceptions of poultry farming.

The questionnaire to the other stakeholders also included socio-economic data, the type of poultry concerned (local or exotic breed) and general perceptions of the trade in poultry and poultry products.

Preliminary versions of the questionnaires were pre-tested with farmers in the peri-urban area of Nouakchott. The administration of each type of questionnaire (the final versions) lasted 30 minutes.

\subsubsection{The Surveys}

In Nouakchott, Assaba and the Hodh El Gharbi, the interviews were conducted in Assania which is the indigenous Arabic language of Mauritania, while the Pular and the Soninke languages were used for the survey in Guidimaka region, with the assistance of the same translator who was one of the project facilitators. The questionnaires were checked for accuracy immediately after the interviews. Farm-level surveys were conducted in two phases during two missions in the three regions. Depending on the working conditions imposed, surveys were feasible in only two villages in each region. In Assaba, the villages of Boumlana and Mouchgag, which were located about $7 \mathrm{~km}$ from the town of Kiffa on Aioun road have been chosen. In the Hodh El Gharbi, the villages included those of Soguenni-Zemal and Oued-M'hamed located respectively $35 \mathrm{~km}$ and $10 \mathrm{~km}$ from the city of Aioun. In Guidimaka, the villages of Arsana and Goupoumody had been involved. Surveys conducted in Nouakchott took place during the whole period of the study, because of promiscuity and convenience. A total of sixty-five (65) small-scale poultry farmers were surveyed.

Surveys to the other actors (sellers of live chickens, egg sellers and sellers of cooked chickens and eggs) were carried out only in Nouakchott as there were no poultry markets in the regions. A total of twenty (20) live chicken sellers from Nouakchott poultry market, 20 egg sellers and 20 sellers of cooked chickens (restaurants) in the popular neighborhoods of Sebkha (5th Arrondissement) and El Mina (6th district) as well as Ilot K and Bagdag neighborhood were surveyed.

\subsubsection{Ethics Declaration}

All participating households were informed about the purpose of the study and that their participation was voluntary and anonymous. Verbal consent was obtained from each household and documented in the questionnaire. Prior to the study, project team members had a meeting in each region to discuss with members of the program's core committee about the questions contained in the questionnaires. The study procedure had also been submitted to the FAO / IFAD Associate Poultry Adviser (APA) Committee in Italy, which had approved it in accordance with their respective standards for ethics in research involving humans.

\subsubsection{Data Analysis}

Data were subjected to EPI INFO statistical software version 3.5.3. The averages of numerical data as well as the frequencies of the qualitative data were calculated for the different regions.

\section{Results}

\subsection{Characteristics of the Actors and their Products}

Socio-economic data for poultry farmers are shown in Table 1. Overally, this table shows that at the start of the ProLPRAF project, $65.0 \%$ of small-scale poultry farmers were female compared to $35.4 \%$ male, and their mean age was $45.3 \pm 8.40$ years. However, the analysis by region shows that in the city of Nouakchott, poultry farming was mostly practiced by men (100\%). Indeed, in the city of Nouakchott, poultry farming involved broiler chickens $(100 \%)$ for meat production, imported from Morocco or Senegal with an average flock size of $432 \pm$ 95.3 chickens. In the regions, poultry farming was practiced in rural areas by women with an average flock size of $15.0 \pm 3.30$ chickens in Assaba; $9.10 \pm 2.10$ in the Hodh El Gharbi and 23.0 \pm 8.20 in Guidimaka. 
Table 1. Characteristics of producers in small-scale poultry farming in Mauritania at the start of the ProLPRAF project (n: 65)

\begin{tabular}{|c|c|c|c|c|c|c|c|}
\hline \multirow[t]{3}{*}{ Regions } & \multicolumn{6}{|c|}{ Parameters } & \multirow{3}{*}{$\begin{array}{l}\text { Average flock } \\
\text { size (head) M (SD }\end{array}$} \\
\hline & \multicolumn{2}{|l|}{ Gender } & \multirow{2}{*}{$\begin{array}{l}\text { Age (year) } \\
{ }^{*} \mathrm{M}(\mathrm{SD}) \\
\end{array}$} & \multicolumn{3}{|c|}{ Type of chickens } & \\
\hline & $\begin{array}{l}\text { Female } \\
(\%)\end{array}$ & $\begin{array}{l}\text { Male } \\
(\%)\end{array}$ & & $\begin{array}{l}\text { Broiler } \\
\text { Chicken }(\%) \\
\end{array}$ & $\begin{array}{l}\text { Local } \\
\text { Chickens (\%) }\end{array}$ & $\begin{array}{l}\text { Guinea fowl } \\
\text { and others }(\%)\end{array}$ & \\
\hline Nouakchott & - & 100 & $50(6.13)$ & 100 & - & - & $432(95.3)$ \\
\hline Assaba & 67.0 & 33.3 & $41.4(10.4)$ & - & 100 & - & $15.0(3.30)$ \\
\hline Hodh El Gharbi & 79.2 & 20.8 & $46.0(13.6)$ & - & 79.2 & 20.8 & $9.10(2.10)$ \\
\hline Guidimakha & 100 & & $44.3(14,8)$ & & 90.0 & 10.0 & $23.0(8.2)$ \\
\hline Total & 65.0 & 35.4 & $45.3(8.40)$ & 17 & 74.2 & 8.9 & \\
\hline
\end{tabular}

*M: mean

SD: standard deviation

Table 2 shows that hundred percent of poultry sellers in Nouakchott live bird market were male and their average age was $34.8 \pm 5.2$ years. These traders sold all categories of poultry at the same time depending on availability (traditional chickens, exotic chickens, ducks, pigeons etc.). The origins of traditional chicken were different: they would come either from the region of Nouakchott and other regions ( $40 \%$ of cases), either from the countryside of the others regions (40\%), or imported from neighboring countries of Mali and Senegal (20\%).

Table 2. Characteristics of chicken sellers and origins of the chickens in Nouakchott live bird market at the start of the ProLPRAF project ( $\mathrm{n}: 20$ sellers)

\begin{tabular}{llllllllll}
\hline Gender & \multicolumn{3}{l}{$\begin{array}{l}\text { Mean Age } \\
\text { (year) *M (SD) }\end{array}$} & \multicolumn{2}{l}{ Origins of traditional chickens and mean flock size } & \multicolumn{2}{l}{$\begin{array}{l}\text { Origins of Broiler chickens } \\
\text { and mean flock size }\end{array}$} \\
\hline Male & Female & & $\begin{array}{l}\text { Nouakchott and } \\
\text { other regions (\%) }\end{array}$ & $\begin{array}{l}\text { Other } \\
\text { regions } \\
(\%)\end{array}$ & $\begin{array}{l}\text { Mali or } \\
\text { Senegal } \\
(\%)\end{array}$ & $\begin{array}{l}\text { Mean flock } \\
\text { size (head) }\end{array}$ & $\begin{array}{l}\text { Morocco } \\
(\%)\end{array}$ & $\begin{array}{l}\text { Senegal } \\
(\%)\end{array}$ & $\begin{array}{l}\text { Mean flock } \\
\text { size (head) } \\
\text { M (SD) }\end{array}$ \\
\hline $100 \%$ & - & $35.0(5.20)$ & 40 & 40 & 20 & $21(4.2)$ & 85 & 15 & $105(15.5)$ \\
\hline
\end{tabular}

*M: mean

SD: standard deviation

The actors involved in retail egg sales were individuals of both sexes with mean age of $30.8 \pm 5.97$ years (Table 3 ). Eggs were imported from Morocco (55\%) or Senegal (45\%). Average maximum number of egg sold per day seemed to be around 3 trays of 30 eggs, while the minimum number was about 1.5. Average egg unit price was about $43.0 \pm 5.0 \mathrm{MU}$, which was comparable to egg price in neighboring countries.

Table 3. Characteristics of chicken eggs sellers and origins of egg in Nouakchott city at the start of the ProLPRAF project ( $\mathrm{n}: 20$ sellers)

\begin{tabular}{llllllll}
\hline Gender & $\begin{array}{l}\text { Mean age } \\
(\text { year }){ }^{*} \mathrm{M}(\mathrm{SD})\end{array}$ & \multicolumn{2}{l}{ Origins of the eggs } & \multicolumn{2}{l}{$\begin{array}{l}\text { Daily sale (Number of } \\
\text { trays of 30 eggs) M (SD) }\end{array}$} & $\begin{array}{l}\text { Mean egg price (UM) } \\
\text { M (SD) }\end{array}$ \\
\hline $\begin{array}{l}\text { Male } \\
(\%)\end{array}$ & $\begin{array}{l}\text { Female } \\
(\%)\end{array}$ & & $\begin{array}{l}\text { Morocco } \\
(\%)\end{array}$ & $\begin{array}{l}\text { Senegal } \\
(\%)\end{array}$ & $\begin{array}{l}\text { maximum } \\
\text { minimum }\end{array}$ & \\
\hline 50 & 50 & $30.8(5.97)$ & 55 & 45 & $2.75(0.7)$ & $1.45(0.5)$ & $43(4.7)$ \\
\hline
\end{tabular}

*M: mean

SD: standard deviation

Poultry meat cooked in neighborhood restaurants of Nouakchott city came either from the city's broiler farms $(45 \%)$ or imported frozen poultry meat (55\%). Traditional chicken was totally absent in restaurants $(0 \%)$ (Table 4). 
Table 4. Characteristics of cooked poultry products in Nouakchott city at the start of the ProLPRAF project ( $\mathrm{n}$ : 20 sellers)

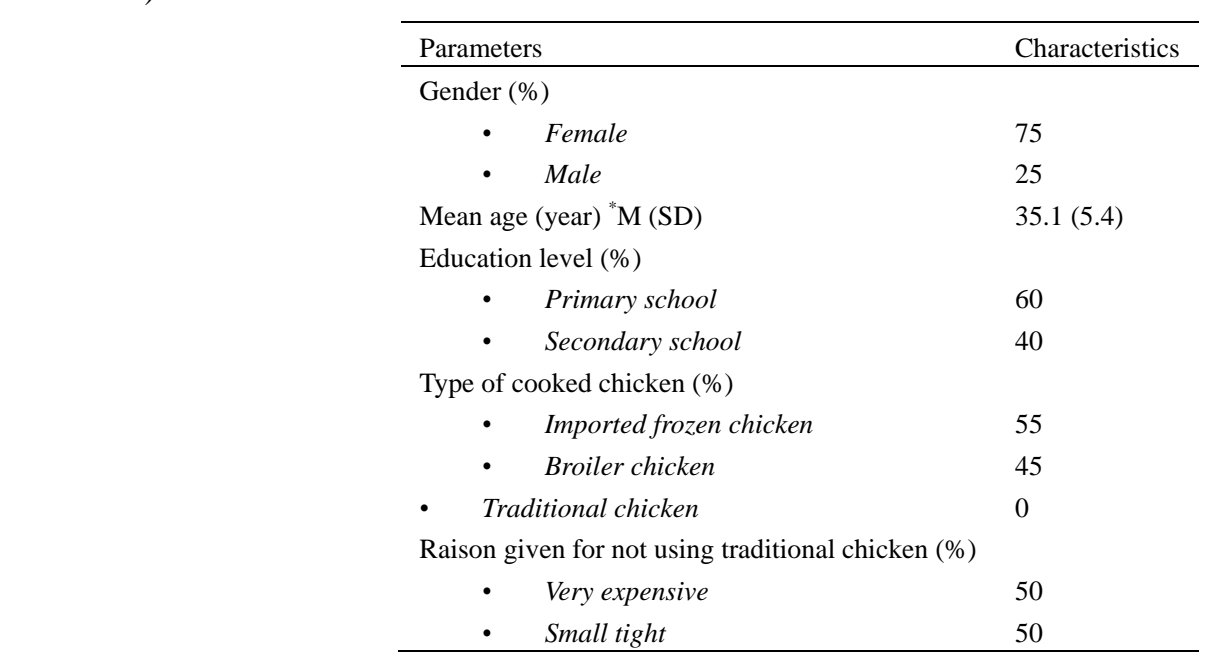

*M: mean

SD: standard deviation

\subsection{Characteristics of Marketing}

Informations on sale and performance improvement of traditional local chicken are presented in Table 5. This table shows that in rural areas, traditional chicken was marketed because hundred percent (100\%) of farmers surveyed in Assaba and Guidimaka regions were selling their chickens and ninety five percent $(95 \%)$ in the Hodh el Gharbi were also selling. However, there were no specific poultry markets or sales outlets, and as a result, most sales were done locally within households (100\% in Assaba, $83.3 \%$ in the Hodh and $80 \%$ in Guidimaka), while the remaining sales were ambulatory (12.5\% in the Hodh and $20 \%$ in Guidimaka). Most farmers (86.7\% in Assaba, 62.5\% in the Hodh and 60\% in Guidimaka) were looking for more efficient breed to improve the productivity of their flock. The purpose of the improvement was to get bigger size of chicken or hens laying more eggs (53.3, 29.2 and 30\% of respondents respectively for Assaba, Hodh and Guidimaka regions).

Table 5. Marketing and improvement of traditional chicken performances $(\%)$ in rural areas of Mauritania $(\mathrm{n}=$ 50 farmers)

\begin{tabular}{|c|c|c|c|}
\hline \multirow[t]{2}{*}{ Parameters } & \multicolumn{3}{|l|}{ Regions } \\
\hline & Assaba & Hodh El Gharbi & Guidimakha \\
\hline Household selling their chickens & 100 & 95 & 100 \\
\hline \multicolumn{4}{|l|}{ Place of sale } \\
\hline - Onfarm & 100 & 83.3 & 80 \\
\hline - Ambulatory & 0 & 12.5 & 20 \\
\hline Looking for improved chicken & 86.7 & 62.5 & 60.0 \\
\hline \multicolumn{4}{|l|}{ Breed of the improved chickens } \\
\hline - $\quad$ Crossbred & 46.7 & 16.7 & - \\
\hline - Traditional & 40 & 45.8 & 60 \\
\hline \multicolumn{4}{|l|}{ Reason for seeking improved birds } \\
\hline - Bigger size & 33.3 & 25 & 10 \\
\hline - $\quad$ Big size and High laying performances & 53.3 & 29.2 & 30 \\
\hline - $\quad$ Higher laying performance & - & 8.3 & 20 \\
\hline
\end{tabular}

\subsection{Production and Marketing Constraints of Village Chicken in Mauritania}

Table 6 presents the production and marketing constraints. The production constraints that hindered the marketing of chicken in Mauritania were mainly those related to the chicken breed, which was small and did not correspond to market demand. Indeed, 66.7\% of farmers in Assaba, 33.3\% in Hodh and 19\% in Guidimaka expressed the need to have more efficient breed for sale as well as for production profit. Another factor limiting the trade was the lack of poultry market in the regions. There was only one poultry market in Nouakchott the 
capital, while in the regions, even in the urban centers there were no poultry markets, meaning that the sales were random. The data showed that the need for market was strong in Assaba (66.7\%) and Hodh (58.3\%). In Guidimaka, things seemed better organized because customers often went to buy on-farm or may ask for the producer to deliver on a donkey (only $10 \%$ of farmers expressed the need for poultry market).

Table 6. Production and marketing constraints (\%) of village chicken in Mauritania ( $\mathrm{n}=50$ farmers

\begin{tabular}{llll}
\hline Parameters & Regions & & \\
\hline & Assaba & Hodh El Gharbi & Guidimakha \\
\hline Housing issues & 100 & 83.3 & 100 \\
Feeding constraints & 73.3 & 70.8 & 100 \\
Health and miscellaneous constraints & 80 & 100 & 70 \\
Poor genetic potential of local birds & 66.7 & 33.3 & 10 \\
Lack of poultry market & 66.7 & 58.3 & 10 \\
\hline
\end{tabular}

Average daily number of egg sold was about 16 for broilers chickens compared to 7 for traditional chickens. The price of traditional chicken ranged between $1385 \pm 126$ and $2325 \pm 275 \mathrm{MU}$, while the corresponding values for broiler chicken were $1255 \pm 60$ and $1470 \pm 47 \mathrm{MU}(1 \mathrm{UM}=0.004 \mathrm{USD})$ (Table 7).

Table 7. Costs and utilisation of chickens in Nouakchott city $(\mathrm{N}=40)$

\begin{tabular}{lllllll}
\hline & $\begin{array}{l}\text { Daily sale } \\
\text { (head) M (SD) }\end{array}$ & $\begin{array}{l}\text { Minimal selling } \\
\text { price (UM) M (SD) }\end{array}$ & $\begin{array}{l}\text { Maximal selling } \\
\text { price (UM) M (SD) }\end{array}$ & $\begin{array}{l}\text { Family } \\
\text { consumption (\%) }\end{array}$ & $\begin{array}{l}\text { Sacrifices and } \\
\text { rites }(\%)\end{array}$ & $\begin{array}{l}\text { Restaurants } \\
(\%)\end{array}$ \\
\hline $\begin{array}{l}\text { Traditional } \\
\text { chickens }\end{array}$ & $6.95(1.4)$ & $1385(126)$ & $2325(275)$ & 25 & 75 & 0 \\
Broiler chickens & $16.2(3.9)$ & $1255(60.5)$ & $1470(47)$ & 55 & 0 & 45 \\
\hline
\end{tabular}

Traditional chickens purchased at Nouakchott live birds market were much more for ritual traditions and practices $(75 \%)$ than for home consumption (25\%) (Table 7). Broiler chicken was bought for home consumption (55\%) but also for restaurants (45\%).

Marketing constraints of traditional chicken were related to the fact that these chickens had small size and were more expensive compared to broilers. For example, $25 \%$ of salespeople surveyed thought that traditional chicken could be more valued in the market if it had a larger size, while $75 \%$ thought that in addition to the large format the purchase price on farm also had to be low if local chickens have to be competitive in the market.

\section{Discussion}

\subsection{Poultry Production Constraints in Mauritania before the PROLPRAF Program}

Poultry farming in rural areas concerned exclusively the traditional chicken that was often associated with pigeons, and guinea fowl. This reflected the composition of rural poultry flocks reported in other countries such as Burkina Faso (Pousga \& Boly, 2009) and Chad (Mopaté, Ndjimtoloum, \& Guéye, 2011). Production constraints remained also the same as those encountered in village poultry farming in developing countries in general (Gueye, 1998; Permin, Peterson, \& Riise, 2001; Pousga \& Boly 2009). These included issues related to health, nutrition and housing conditions, and this had been also mentioned in Mauritania (Salissou, 2011). The special constraint here was that poultry farming was not considered as domestic animal activity, and poultry meat was not part of the habits of meat consumers. In this country, the importance of the breeder was defined by the number of cattle, camels, sheep and goats. An FAO study (FAO, 2002) showed that the livestock sector was the sector where social solidarity mechanisms were most prevalent. The study reported that traditional Mauritanian societies were deeply influenced by Islam and included many mechanisms for redistributing wealth and supporting the poorest. However, these mechanisms to combat poverty from livestock were not taking into account poultry, which was not considered as farm animal before. Indeed, poultry was minimized and was mostly considered as children's activity. Moreover, the Ministry in charge of livestock did not have any poultry support program and the Veterinary Services Direction also did not import poultry products. All these factors, which were unfavorable to the development of poultry sector, made poultry and its culture little known to Mauritanian farmers. For example, poultry producers were not aware that chicken and even eggs did not support heat as chicken houses were made of metallic materials (sheet, barrel and containers) often disposed in full sun. This housing conditions was also seen in chicken's production in Nouakchott with no fence or window in broiler houses. 


\subsection{Marketing Constraints}

The day-old chick was imported from either Morocco (85\%) or Senegal (15\%) together with food and veterinary products. This finding was also highlighted by other studies (FAO 2009; Salissou 2011). Chick rearing was done in the family or on the peripheries of the city until the age of 27 days when chickens were transferred to the market. It should be noted that broiler farming continued on the market at the same time as sale, and often under contract (if the seller does not own the chickens or the chicken house).

The fact that consumers were looking for big size meat implied that they were interested in the size and not in the taste and flavor of the meat, as in other African countries (Pousga, 2007; Kyarisiima, Naggujja, Magala, Kwizera, Kugonza, \& Bonabana-Wabbi, 2011). Broiler chicken was significantly cheaper than traditional chicken which was more expensive, even compared to the price of local chicken from other countries (Mopaté et al., 2011). This price situation for traditional chicken in Mauritania could be partially justified by the slow production of traditional chicken (sold between 1-3 years) probably because of the low production inputs compared to the countries of the sub-region. The high market price of local chicken could also be explained by the fact that most of these chickens were imported from neighboring countries, and this also justified the low consumption of this type of chicken in Nouakchott compared to other capital like Ouagadougou in Burkina Faso (Ouedraogo \& Zoundi, 1999; MRA, 2007), and N'Djamena in Chad (Mopaté et al., 2011), where traditional chicken from rural areas represent the most important poultry meat in the big cities. The reasons for not using local chicken at the restaurant were due to high cost associated with small size, which did not allow to make a profit after preparation and sale. Furthermore, consumers might complain when small size of chicken meat were served to them and especially if the legs were small. This situation in Mauritania differed from the general perception of African populations regarding traditional chicken meat. Indeed, in Africa, the taste of meat from traditional poultry is generally still preferred compared to poultry from modern farms (Sodjinou, 2011; Kyarisiima et al., 2011) despite the small size.

\subsection{Evolution of the Situation and Impact of ProLPRAF Program}

Under the influence of ProLPRAF programm, nowadays, there are nearly hundred semi-intensive and complex poultry farms operating in the country, including about sixty in Nouakchott, owned and managed either by rural producer organizations (cooperatives, unions) or private operators, who have invested in the sector (N'Diaye, 2016). With the evolution, population growth and behavioral change, white meat (Halal) has returned to the habits of Mauritanian consumers and the country is facing a situation where local production could no longer meet the needs of consumers. Massive imports of frozen poultry meat from developed countries also contributed to challenge the development of village poultry farming, in the sense that these frozen chicken meats came from poultry complexes with large-sized chickens that attracted more the consumer. This situation promoted the development of small broiler farms throughout the city of Nouakchott. However, it is important to note that at the start of the ProLPRAF in 2011, the day-old chick and all its food were imported and only the breeding took place in Mauritania. The impact of ProLPRAF is perceptible today in sectorial policies and their implementation methods (N'Diaye, 2016). Indeed, the supervisor of the Program (the Ministry of Rural Development) has taken over the value chain vision and value chain approach in its Rural Sector Development Strategy (SDSR) by 2025, in which poultry farming and other value chains promoted by ProLPRAF are recognized as priority sectors. In addition, this Ministry has put in place tools and facilities to reinforce training and development in the poultry sector, through the creation of Value chain department in the Ministry of Livestock, the introduction of a "poultry farming" module at the Technical High School in Boghé, as well as the implementation within the framework of a Public Private Partnership (PPP) of a large poultry complex in Nouakchott, intended to facilitate the provision to national operators and stakeholders in day-old-chicks and other inputs.

\section{Conclusions and Recommendations}

This study gave knowledge on the status of poultry farming in Mauritania before the activities of the ProLPRAF program. Livestock had played a very important socio-religious role in Mauritania where there were social support mechanisms to fight against rural poverty. But these mechanisms to fight Poverty from livestock did not consider poultry that was not part of livestock in the country. Poultry farming was thus challenging with social and even political constraints which limitted its development. In such a situation, the concept of fighting poverty through poultry farming seemed inappropriate in a society where poultry had no prerogatives. However, the ProLPRAF has been able to meet this challenge because it is undoubtedly under the incentive of this Program that the poultry industry has experienced a boom and renewed exceptional dynamism seen nowadays in Nouakchott as well as inside the country. 


\section{Acknowledgements}

This work was realized thanks to the Associate Poultry Advisor (APA) Program of the Food and Agriculture Organization of the United Nation (FAO), which provided financial support for staying in Nouakchott in Mauritania to join the activities of the POLPRAF program.

\section{References}

FAO (2002). Initiative, Elevage, Pauvreté et Croissance. Volume I, II et III.

FAO (2009). Revue du Secteur avicole. Revue réalisée par Moctar Fall, Mauritanie.

FAO (2010). Manuel de formation à la lutte contre la désertification, à la fixation des dunes et à la gestion des boisements en Mauritanie. FAO, APEFE, MDR, Mauritanie, Nouakchott, Décembre 2010.

IFAD (2014). Programme de lutte contre la Pauvreté Rurale par l'Appui aux Filières (ProLPRAF). Rapport de revue à mi-parcours.

Gueye, E. F. (1998). Village egg and fowl meat production in Africa. World's Poultry Science Journal, 54, 73-86. https://doi.org/10.1079/WPS19980007

Kyarisiima, C. C., Naggujja, F. A., Magala, H., Kwizera, H., Kugonza, D. R., \& Bonabana-Wabbi, J. (2011). Perceived tastes and preferences of chicken meat in Uganda. Livestock Research for Rural Development, 23(11). Retrieved from http://www.lrrd.org/lrrd23/11/kyar23242.htm

Mopaté, L. Y., Ndjimtoloum, N., \& Guéye, E. F. (2011). Characteristics and Destinations of Indigenous Chickens Marketed in Guéra Region, East-Central Chad. International Journal of Poultry Science, 10(9), 721-725. https://doi.org/10.3923/ijps.2011.721.725

MRA: Ministère des Ressources Animales. (2007). Diagnostic de la filière de l'aviculture Traditionnelle au Burkina Faso. Rapport provisoire. Burkina Faso. pp. 117.

N'Diaye, S. (2016, Septembre). Aviculture en Mauritanie : Le boom de la filière volaille. Magazine Afrik Tandem-Medias, No 1, Nouakchott, Mauritanie.

Permin, A., Peterson, G., \& Riise, J. C. (2001). Poultry as a tool for poverty alleviation.In: R. G. Alders \& P. B. Spradbrow (Eds.), Opportunities and problems related to poultry production at the village level: Workshop on Newcastle Disease control in village chickens. Retrieved from www.aciar.gov.au/publication/PR103

Pousga, S., Boly H., Lindberg J.E., \& Ogle B. (2005). Scavenging chicken in Burkina Faso: Effect of season, location and breed on feed and nutrient intake. Tropical Animal Health and Production, 37, 623-634. https://doi.org/10.1007/s11250-005-4304-1

Pousga, S., \& Boly, H. (2009). Overview of research on poultry in Burkina Faso. Family Poultry, 18(1\&2).

Salissou, I. (2010). Evaluation de la productivité et la commercialisation des produits de l'aviculture familiale dans les Oasis et au Guidimakha en République Islamique de Mauritanie. FAO, APA report 2010. Family Poultry Communications, 19(2), 24-28.

Sodjinou, E. (2011). Poultry-Based Intervention as Tool for Poverty Reduction and Gender Empowerment: Empirical Evidence from Benin. (Unpublishd Doctoral Thesis). Institute of Food and Resource Economics. Faculty of Life Science. University of Copenhagen. pp. 239.

FAO (2000). Projet de gestion des parcours et de développement de l'élevage. Etude d'impact environnemental. FAO/BAD. Rapport No. 00/025 ADB-MAU. Retrieved from https://www.afdb.org/fileadmin/uploads/afdb/Documents/Environmental-and-Social-Assessments/ADF-BD -IF-2000-127-FR-MAURITANIE-EIE-PROJET-DE-GESTION-DES-PARCOURS-ET-DE-DEVELOPPEM ENT-DE-LELEVAGE.PDF

Ouedraogo, S., \& Zoundi, J. S. (1999). Approvisionnement de la ville de Ouagadougou en poule t de chair. Agriculture Urbaine en Afrique de l'Ouest, IDRC, Canada.

World bank (2018). Country Prolfile. World Development Indicators database: Mauritania. Retrieved from https://databank.worldbank.org/data/views/reports/reportwidget.aspx?Report_Name=CountryProfile\&Id=b4 50fd57\&tbar=y\&dd=y\&inf=n\&zm=n\&country=MRT

\section{Copyrights}

Copyright for this article is retained by the author(s), with first publication rights granted to the journal.

This is an open-access article distributed under the terms and conditions of the Creative Commons Attribution license (http://creativecommons.org/licenses/by/3.0/). 